\title{
The First Rule of Judging Club...: Inside the Saltire Society Literary Awards
}

\author{
Stevie Marsden ${ }^{1 *}$, Claire Squires ${ }^{2}$ \\ ${ }^{1}$ CAMEo Research Institute for Cultural and Media Economies, University of Leicester, UNITED KINGDOM \\ ${ }^{2}$ University of Stirling, UNITED KINGDOM
}

*Corresponding Author: stevie.marsden@leicester.ac.uk

Citation: Marsden, S. and Squires, C. (2019). The First Rule of Judging Club...: Inside the Saltire Society Literary Awards, Journal of Cultural Analysis and Social Change, 4(2), 10. https://doi.org/10.20897/jcasc/6354

Published: December 11, 2019

\begin{abstract}
Book awards are a pervasive aspect of contemporary book culture, attracting both substantial media and scholarly attention. They confer prestige, create marketing opportunities, push sales, and contribute to the early stages of canon formation. Yet, beyond occasional media splashes when judges break ranks and disagree, there is little insight into the administrative and decision-making processes inside book awards. This article draws on the autoethnographic experiences of two academic researchers, who were simultaneously participants (as administrator and judge) for the Saltire Society Literary Awards. In so doing, the article gives insight into particular moments within the administration and judging of the awards, such as changes instigated by research findings and debates surrounding gender imbalance in Scottish literary award culture. It also examines some of the challenges of operating as embedded researchers. The article analyses what autoethnographic methods can bring to an understanding of the Saltire Society's Literary Awards and other cultural awards, and the implications of embedded research and collaborative autoethnography for 21 st century book culture scholarship more widely. It reflects upon modes of embedded research by making evident the challenges and dilemmas of researching from the 'inside'. The ethical framework for such research is far from simple, but in exploring particular moments with perspectives from both inside and outside the judging processes, and in interrogating the practices of literary consecration, the article casts light upon this particular 'judging club' and its practices, and illuminates ways in which researchers might consider, orientate, and carry out further research into processes of cultural consecration.
\end{abstract}

Keywords: literary awards, literary prizes, autoethnography, embedded research, Saltire Society, judging, cultural consecration, literary gatekeeping

\section{INTRODUCTION}

Book awards are a pervasive aspect of contemporary book culture, attracting substantial media and scholarly attention (Auguscik, 2017; Cain, 2018; English, 2004, 2005, 2013; Flood, 2017, 2018a, 2018b; O'Brien, 2017; Squires, 2007a, 2007b, 2007c, 2007d, 2013; Roberts, 2011; Ramdarshan Bold and Norrick-Rühl, 2017). They confer prestige (English, 2005), generate marketing opportunities (Squires, 2007a), increase sales (The Guardian, 2012; Menon, 2013), and contribute to the early stages of canon formation (English, 2005: 154, 2005: 245; Corse, 1996: 101). Yet, beyond occasional media splashes when judges break ranks and disagree (Flood, 2011; Rahim 2012), there is little insight into the inner workings of administrative and decision-making processes of book awards. Discussions of award culture are, as Moeran suggests, largely 'second-hand reports on what actually goes on during the jurying process' (2012: 3). This article offers a different kind of account of literary award culture - that of the 'researcher-in-residence' and 'researcher undercover' - and draws upon substantial participant observation and 
autoethnography of the Saltire Society and its series of Literary Awards from 2011-2015. The authors of this article were 'inside' the awards, an opportunity rarely afforded to either scholarly or journalistic accounts of literary prizes, thereby offering significant insight into a particular example of literary gatekeeping. It takes a micro-analytical approach deriving from its deep immersion in one particular set of awards, but draws on selected comparative evidence to show how the Saltire Society Literary Awards may be similar to or diverge from other book prizes.

Founded in 1936, the Saltire Society is a cultural charity which seeks to 'preserve all that is best in Scottish tradition and to encourage new developments which can strengthen and enrich the country's cultural life' (Saltire Society, 2016). To achieve this aim, the Society administers awards for art, civil engineering and heritage, as well as its Literary Awards. By 2018, there were six Literary Award categories: Fiction, Non-Fiction, First Book (established 1988), History (established 1965), Poetry (established 2014) and Research (established 1998). Between 1982-2015, all fiction, non-fiction and poetry books were considered for the Book of the Year Award (established 1982), but since 2015 these have been judged in their respective categories, with an 'overall' winner selected from the six categories. To be eligible for the Society's Literary Awards, a book must be written by 'a living author of Scottish descent or residing in Scotland' or deal with 'the work or life of a Scot - or a Scottish question, event or situation' (Saltire Society, 2014).

The Saltire Society is a small, Edinburgh-based organisation, with a membership base from across Scotland and beyond. During the period under consideration in this article, the Society was staffed by an Executive Director, a Programme Manager and, at times, an Events Assistant, in addition to the role undertaken by Stevie Marsden, as described below. An external PR agency was taken on during some of the years under consideration, to promote the Society's awards in the media. The Society's Literary Award judges were generally selected on recommendation of existing judges, with turnover largely operating on a one-in-one-out system. Although terms of office were discussed by the Society (both by administrators and judges themselves), ever since the Literary Awards panel was instated in 1982, many of the judges served substantial periods, with the longest panel member serving for over 34 years (despite the Society's other awards panels adhering to strict terms of office ranging from three to five years). While this is unusual practice for many literary awards - the Man Booker, Women's Prize for Fiction and Costa Book Awards have new judging panels each year, for example - there are some prizes, such as the Nobel Prize in Literature (selected by the Swedish Academy whose members are elected for life), and the Prix Goncourt in France (which stipulates that 'jury members be selected by their peers and elected to the Académie Goncourt for life' (Pickford, 2011: 227)) that have long terms of service for judges. Due to its evidence base, this article does not compare the practices of an 'academy-style', long-serving set of judges, to those who are appointed each year, although the long-serving nature of the Society's judges forms part of the discussion. During the time we were involved, judges were not paid for their labour, but travel and subsistence expenses incurred whilst completing judging duties (such as attending panel meetings and events) were covered by the Society.

Our respective roles as judge and administrator provided unparalleled access to the operations of the Society's Literary Awards. This access and insider perspective - made possible through our respective roles as a Literary Award judge (2011-2014) and through completion of an Arts and Humanities Research Council Collaborative Doctoral Award (AHRC CDA) with the Society (2012-2016) - allowed unique insight into the operations of a literary and cultural institution and its production of literary value. (The purpose of AHRC CDAs was to give doctoral researchers 'first hand professional experience outside the university environment' and to 'encourage and establish longer-term links between the partners [university and organisation] that can have benefits for both' (AHRC, 2015: 3)). Through an analysis of key moments experienced during our time working with the Society, this article examines the Awards within the broader thematic contexts of literary award culture. These contexts include the fallibility of processes of judgement (Moeran, 2012), the allocation and power dynamics of cultural value (Belfiore, 2018), and gender disparity in award culture (Demoor et al, 2008; Griffith, 2015; Marsden, 2019). Furthermore, this article reflects upon embedded research (via schemes including the AHRC CDA), the opportunities and challenges it brings to bear on data collection and analysis, and the ethical framework of such intertwined partnerships. Using the Saltire Society Literary Awards as a case study, this article demonstrates how autoethnographic methods can contribute to the study of book awards and book culture more generally.

\section{STRUCTURE AND APPROACH}

This article is structured so as to foreground the experiences of its two authors, using Finlay's articulation of the role of 'qualitative researchers' who are 'engaged in contemporary practice, [where...] the researcher is a central figure who influences, if not actively constructs, the collection, selection and interruption of data.' (Finlay, 2002: 212).

Both authors had roles in the 'collection, selection and interruption of the data' discussed in this article: Claire as judge and doctoral supervisor, and Stevie as an administrator of the awards and doctoral researcher. Following Finlay, we 'recognize that research is co-constituted' and a 'joint product of participants, researcher and their 
relationship' (Finlay, 2002: 212), and thus the purpose of this article is to examine our experience of those roles and the impact they had on our research and work at the Society.

Our methodological approach is autoethnographic. Using fieldnotes, reminiscences and contemporaneous documentation, we consider particular moments which occurred between 2011-2016 and contextualise these in relation to key themes. We approach autoethnography through Chang's assertion that it 'combines cultural analysis and interpretation with narrative details' (Chang, 2008: 46). Moreover, our analysis aligns with Chang's term 'collaborative autoethnography' which sees 'the collaborating researchers interact dialogically to analyse and interpret the collection of autobiographic data' (Chang, 2013, cited by Lapadat, 2017: 598).

Much scholarship details the nuances and complexities of autoethnography as a research method (Bochner, 1997; Bruner, 1993; Denzin, 1989; Ellis and Bochner, 2000; Freeman; 2004) and considers its advantages and limitations (Denzin, Lincoln \& Smith, 2000; Méndez, 2013). While it is not the purpose of this article to discuss these accounts in detail, such scholarship underpins our study. Of particular use to us is the work of Barton, who has explored the ethical dilemmas inherent in autoethnographic work (Barton, 2011). Existing autoethnographic approaches to publishing and literary culture (Radway, 2000; Wulff, 2017) have set a precedent for our analysis, with Moeran's article 'How to Award a Prize: An Ethnography of a Juried Ceramic Art Exhibition in Japan' making a key intervention to the field of ethnography and award culture, in its opening up of the 'black box for scholars', of 'how prizes are allocated' (Moeran, 2012: 3).

Alongside archival records, transcripts of interviews and judging meetings, this article combines fieldnotes from 2011-16 with reflective analysis, prompted either by fieldnotes or the recollection of significant events. As Coffey argues, memory is an imperative and valid resource for the ethnographer:

Our memories are what enable us to reflect upon and locate our fieldwork experiences (...) ethnography is in itself an act of collective and individual memories. Texts of the field are constructed from data that are the memorabilia of fieldwork (Coffey, 1999: 110).

Our co-writing assumes a shared first-person plural voice throughout, although we also refer to ourselves in the third person ('Claire', 'Stevie') when describing our roles (all other individuals are anonymised). In italicised first person singular reflective notes, we present the 'narrative details' (Chang, 2013) of our individual experiences. The subsequent sections of this article, Multiplying Roles, Instigating Change, and Gender and Judging, detail how we navigated our roles within the Society, illustrate how we used our knowledge and experience to make recommendations and enact change, and contextualise our observations and research in relation to the issue of gender in award culture.

\section{MULTIPLYING ROLES}

Claire was invited to become a judge for the Saltire Society Literary Awards in 2011, after recommendation for the role by a former judge. Claire described her initial involvement:

I'd gone to visit [the CEO of Publishing Scotland] in her office. I'd just moved to Scotland, and I was doing a round of introducing myself to people. She mentioned that she was a judge for the prizes and my literary prize antenna definitely twitched.

The role of judge involved reading nominated books, participating in judging meetings, and attending and speaking at the announcement events. Claire accepted the invitation to judge, though with some concerns about the amount of reading it would entail, as well as the open-ended nature of the role (as previously noted, there was no formalised system for terms of office for the Society's Literary Awards panel and no term of office was discussed during Claire's appointment, although she recalled in her reflective notes thinking she would serve for three years, but eventually served for four). However, she thought joining the panel would be a good opportunity to read across the output of contemporary Scottish authors and publishers, and see in practice how literary award culture functioned, since this was an area in which Claire had published extensively (see Squires, 2007a, 2007b, 2007c, 2007d; Wischenbart et al., 2010). Until 2013, Claire and her fellow judges would read all books submitted for the Book of the Year and the First Book (including fiction, non-fiction and poetry). ${ }^{1}$ However, in 2013 the Society instituted a new system which partnered judges with one or two others. Submitted titles were divided among each

\footnotetext{
${ }_{1}^{1}$ The Saltire Society Literary Award judges would have had to read anything from 70 to over 100 books each year for the award categories they were judging (although when the pairing system was introduced, this lowered the number of books each judge had to read). The number of books submitted for literary awards generally can vary. When the novelist Val McDermid was a member of the Man Booker judging panel in 2018, she noted that 171 books were submitted for the prize (McDermid, 2018). Kate Williams, chair of the Women's Prize in 2019, commented that she had over 170 titles to read. (Williams, 2019). Alternatively, the chair of the inaugural Jhalak Prize for British or British-resident BAME writers, Sunny Singh, lamented that they had only received 51 submissions for the prize (Cain, 2016).
} 
pairing/group, with the pairing deciding which books from their selection to put forward for the whole panel to read. Claire thus had experience of both judging processes, as discussed in more detail in the next section.

Uniting her post as Professor of Publishing Studies at the University of Stirling, and judging role with the Society, Claire developed a proposal for an AHRC CDA project in 2011 (Squires, 2011). Through this project, the Society would gain a kind of 'researcher-in-residence' who was dedicated to formulating a history of its Literary Awards, as well as becoming involved in their administration. The researcher would be given privileged access to internal documents, communications and staff, as well as being an observing participant of the management of the awards. Stevie was selected as the student to undertake the CDA, from October 2012.

Stevie approached the researcher-in-residence format of the $\mathrm{PhD}$ with an understanding of the two distinct roles she would be performing: doctoral researcher and awards administrator. The latter role would include ensuring the terms of eligibility for the awards were up-to-date and that entries conformed to them (e.g. publication date, entry into the appropriate category), corresponding with publishers, ensuring publishers had submitted books, and arranging and minuting judging meetings. From the beginning, Stevie approached this work as if it were inseparable from her role as doctoral researcher, believing that the two would, and were expected to, intermingle. In the CDA application, it was made clear that the embeddedness of the researcher was intended to contribute to their overall understanding of the awards, with one of the project's objectives being 'establishing a history of the awards (...) via archival research, interviews, observation and participant observation, and contextual study' (Squires, 2011).

When starting her research, Stevie's understanding of participant observation came via Kawulich's description of a 'process enabling researchers to learn about the activities of the people under study in the natural setting through observing and participating in those activities' (2005: 2). However, when writing reflective notes for this article, Stevie wondered whether the intermingling of her roles was in fact the best approach to take:

I perbaps did not consider fully the nuances of this dualistic undertaking, nor did I think about the complexities of the research methods I would be using. On reflection, I realise that I was unprepared for the fact that, at times, it would be difficult to negotiate my two different roles. My roles often required different approaches and priorities to the extent that effective fulfilment of one role could impede the other. For example, I usually had a working role during the Society's awards ceremonies: I would be welcoming guests and handing out goody bags and making sure the judges were ready to make announcements. Such events would likely have been excellent opportunities to gather data but I approached them as an administrator who was trying to make the event run smoothly.

I was an embedded researcher, but I was also a colleague and, eventually friend, to the people I worked with. Even though my colleagues at the Society were aware of my role as a researcher and were perhaps slightly reticent at first because of this, over the years they became more comfortable with me, eventually seeing me, I believe, as a colleague first and researcher second (...) I therefore felt an enduring discomfort regarding the intermingling of my roles.

Claire was similarly positioned between two roles as judge and as Stevie's $\mathrm{PhD}$ supervisor. As she commented in her notes:

This dual role put me in a position where I was an active participant in the processes that Stevie was researching. I was therefore included in her set of semi-structured interviens, was one of the voices captured in her recordings of meetings, and a participant in ber field notes.

Although the other judges and Society staff were obviously aware of my role as Stevie's supervisor, and to a degree of my research interest in literary prizes I think - other than in the most practical terms vis-a-vis my relationship to Stevie - they largely viewed me as a fellow judge. In some ways I suppose I was a researcher under cover - I hadn't intended to use my experience to write about the awards, and the CDA was the academic output I anticipated from my relationship with the Society. However, I found it impossible not to bring my knowledge of other awards, my understanding of their role in the marketing and circulation of books, and my sense, underpinned by that knowledge and understanding, of how cultural award decisions were made, to my thought processes and actions as judge.

The intermingled and multiplying roles of researcher and participant that we both encountered are further explored in the next section, which examines the ways in which we used our knowledge and relationships to instigate change. 


\section{INSTIGATING CHANGE}

The AHRC CDA project came at a significant moment in the recent history of the Saltire Society. In 2010 the Society commissioned a strategic review in order to assess its purpose (Whitekirk, 2011). The review affirmed that the Society was relevant and an important part of Scotland's cultural environment, but that it should reconsider its governance and identity. This conclusion led to the appointment of an Executive Director in 2012. The CDA project, therefore, began at a time of upheaval, but also opportunity for the Society to use Stevie's research, communicated formally via internal reports, to inform changes to the administration of the Literary Awards.

One of the first issues the Executive Director asked Stevie to investigate was whether the introduction of ereaders would help judges and award administrators. As well as pricing e-readers, exploring file formats and methods of delivering e-books to devices, Stevie contacted other literary award administrators to see if they used e-readers, and whether their implementation had been a productive addition to award management. When contacting other award administrators Stevie used her Society email address, believing that awards administrators would be more likely to discuss their practices with a fellow administrator than a doctoral researcher. The report (Marsden, 2013) led to the introduction of e-readers for the judges and a conference paper on whether judging was altered by e-reading (Marsden, 2014a).

However, there were times when the separation of Stevie's roles was not as clear cut. In 2013 Stevie was considering how the awards were perceived by readers, booksellers, publishers and authors, both in terms of prestige (a key research question for her doctoral research) and their marketability. This became a leading question for two reasons. Firstly, after conducting interviews with publishers and authors, Stevie realised there was confusion between the various award categories. Secondly, she thought that the confusion surrounding the awards was having a negative impact on their effective promotion. Prompted by the foundation of the Poetry Book award in 2014, Stevie completed research into how other multi-category awards (such as the Costa Book Awards) functioned, and wrote a report recommending that the Society reconsider the structure of its Literary Awards (Marsden, 2014b). This report provided evidence for change to the structure of the awards which was taken to the Executive Board and, since 2014 (with further developments in 2015 and 2018), was implemented. ${ }^{2}$

Another change introduced while Stevie was working at the Society was the introduction of the 'pairing' system for judges described earlier. The Society was conscious that the onerous level of reading made it difficult to recruit new judges, and so, following discussion with Stevie, the Society introduced pairing. Instead of reading 70-100+ books, judges read around twenty and selected about three or four from their assigned nominations for all judges to read. At the time, Stevie realised this system was imperfect but felt it was the most reasonable way of managing the reading load, whilst ensuring every book was read and discussed by some members of the panel, as she explains:

At the time I was thinking about this more from a logistical point of view and less from a critical point of view. If I had read about this system being implemented for another literary award, I probably would have questioned its legitimacy. I'd always been slightly uncomfortable with the fact that only two or three judges on the panel could read Gaelic and so it was up to them alone to compare Gaelic entries to books in English or Scots and convince their fellow judges of their literary merit (or not, as the case may be), and yet, here I was arguing for the implementation of a system that exacerbated this problem. I knew it was not a perfect solution, however, by this point I also knew that the awards were inherently imperfect beasts, created and managed over the years by individuals who were passionate about Scottish literature, but inconsistent in their administration. As a result, I started to believe that imperfect, compromised change was better than no change at all.

However, despite her initial concerns about the reading load, Claire's notes explained that she found the pairing process problematic:

I wasn't particularly bappy with the decision to pair us up and split the books between us. I worried that this meant some books would be taken out of consideration by some pairs (I felt this specifically bappened to one). There was also the instance, due to administrative error, of one book going to two pairs. My partner and I didn't rate it at all, and wouldn't have put it forward, but the other pair who received it really liked it, and put it through. This, in itself, showed a flaw in the system, and - to my mind - undermined quality processes within the prize.

\footnotetext{
2 While Stevie contacted other literary award bodies to ask about their administrative practices and used other awards as comparative examples when proposing changes, the Saltire Society's Literary Awards were rarely discussed or considered in terms of their status or role within the wider ecosystem of literary awards. Neither Stevie nor Claire recall the Society's administration or Literary Awards judges considering the Awards' reputation in relation to other book prizes, but do recall a focus on how the Saltire Society Literary Awards were perceived within Scottish literary culture, with the Society commonly positioning the awards as 'Scotland's most prestigious literary awards'.
} 
Examples such as the pairing of judges and the restructuring of the awards demonstrate how Stevie's role as a researcher-in-residence at the Society had practical, if ultimately imperfect, consequences. Indeed, Stevie was aware of the almost symbiotic relationship between her roles and believes they were demonstrative of Gale and Wyatt's description of collaborative writing and reflexivity: '[w] here we write becomes what we write [and] what we write becomes where we write' (Gale and Wyatt, 2010: 10). However, in retrospect, Stevie recognises how her two roles affected her approach to her research:

My experience with the Society felt unique in terms of a PhD project, since I was able to consider my research in context
and make tangible changes to the administration of the awards. Part of the purpose of my doctoral research was to construct
a comprehensive history of the awards and their originations and much of this was done through examination of archives at
the National Library of Scotland. But, although I spent many hours alone in the library sifting throngh box files, I never
felt as though I was completing my work in an academic vacuum. Instead, through these internal reports and
recommendations I felt like I was part of the greater narrative of the Society's history. In other words, I was piecing together
a history that I was also helping to shape in the present. However, even though I was happy that my research into the use
of e-readers and multi-category awards led to (what I believed to be) beneficial changes to the administration of the awards,
I think the introduction of the pairing system for judges is an example of my role as an administrator taking over.

Claire's role as a judge, unlike Stevie's, was not configured to instigate change (although her role as doctoral supervisor meant she advised Stevie). Nonetheless, there were various ways in which she acted in order to foster transitions in the awards' processes while she was a judge, including in the quantitatively-oriented approach to decision-making. As Claire details, these prompts to change came in part from her research knowledge of the judging and administration of literary awards, which led to a feeling of dissatisfaction in some meetings:

By my second year, I was finding the processes for deciding on the shortlist and winner frustrating (we decided on the winner at the same time as the shortlist - it was effectively the top ranked book). After some time discussing the (private) longlist of titles, the chair of the judges moved us to a vote. We were asked to rank each title - I think we'd got it down to 8 or 9 , and had to give each one a score. I didn't like this process, but it very much seemed to be what the others were used to doing. We wrote them on pieces of paper, and the scores were totted up. We then dropped some books off the bottom in order to make the shortlist. I was really frustrated by this. The book I ranked the highest had dropped off the list.

There was no real discussion about how the books had been ranked, and about whether it meant that books which were consensus choices made it onto the shortlist by getting $5 s$ and $6 s$, rather than a book which one person bad ranked really bighly, but others seemed to dislike. The process of the ranking was done secretly. I thought this was odd - surely we should be willing to express our opinions? It also meant that whichever book was sitting at the top of the rankings would then become the winner, without any further discussion. This also seemed odd, and didn't seem to work like any other prize I was aware of, where the shortlist decision was made, followed by (some time later) a decision about the winner (allowing time for re-reading). I tried - as far as I remember - to make some semblance of protest, but to no avail.

In her notes, Claire went on to detail how she created a spreadsheet (Figure 1) for that year's post-awards meeting. The spreadsheet, she recalled, included figures she had scribbled down, but as she had not managed to capture them all they were 'balf real, balf made up':

My point, anyway, was to show that numbers weren't objective, and that you needed to decide how you were using numbers in order to have them as part of the judging process. I was urging us to be more discursive in our decisions, and use numbers (if we used them at all) only as a guide.

In so doing, she disputed the seeming clarity of using a quantitative approach to prize decision-making, similar to Moeran's exploration (2012) of the challenge of which numbers should be used. In the spreadsheet, Claire detailed a scenario in which Judges 1-6 ranked and scored nine titles (A-I), with nine being the highest individual score. The top half of the spreadsheet detailed how one title $(\mathrm{H})$ was highest ranked by Judge 4 , but would have dropped out of the shortlist of six (which would produce a shortlist of books A-F, with book A the top-scored book overall). Claire used the lower part of the spreadsheet to detail how this ranking changed if the four lowest marks (scoring 1-4) were taken away from each book, in order to prioritise books which individual judges had ranked highly. Doing this would produce a slightly different shortlist, with books A, B, C, D, E and G in the top six (dropping book F), with books A and D being jointly ranked first. 


\begin{tabular}{|c|c|c|c|c|c|c|c|c|c|c|}
\hline \multicolumn{11}{|c|}{ Book of the Year Award } \\
\hline \multicolumn{11}{|c|}{ NB individual judging patterns are not actual judges } \\
\hline & & & & & & & & & & \\
\hline & A & B & $\mathrm{C}$ & D & E & $\mathrm{F}$ & G & H & I & \\
\hline J1 & 9 & 8 & 8 & 7 & 4 & 6 & 5 & 3 & 2 & 9 \\
\hline $\mathrm{J} 2$ & 9 & 8 & 2 & 1 & 7 & 5 & 4 & 3 & 6 & 8 \\
\hline $\mathrm{J3}$ & 8 & 9 & 6 & 1 & 7 & 3 & 2 & 4 & 5 & 7 \\
\hline 14 & 5 & 5 & 7 & 3 & 2 & 6 & 1 & 9 & 4 & \\
\hline 15 & 8 & 1 & 4 & 9 & 7 & 3 & 6 & 2 & 1 & \\
\hline \multirow[t]{3}{*}{16} & 6 & 5 & 7 & 9 & 1 & 4 & 8 & 3 & 2 & \\
\hline & 45 & 36 & 34 & 30 & 28 & 27 & 26 & 24 & 20 & \\
\hline & & & & & & & & & & \\
\hline \multicolumn{11}{|c|}{ Take away lowest four marks } \\
\hline & A & B & c & $\mathrm{D}$ & E & $\mathrm{F}$ & G & H & I & \\
\hline J1 & 9 & 8 & 8 & & & 6 & & & & \\
\hline $\mathrm{J} 2$ & 9 & & & & 7 & & & & 6 & \\
\hline $\mathrm{J} 3$ & & 9 & & & 7 & & & 4 & 5 & \\
\hline 14 & & & & & & 6 & & 9 & & \\
\hline 15 & & & & 9 & & & 6 & & & \\
\hline \multirow[t]{3}{*}{16} & & & 7 & 9 & & & 8 & & & \\
\hline & 18 & 17 & 15 & 18 & 14 & 12 & 14 & 13 & 11 & \\
\hline & $1=$ & 3 & 4 & & $5=$ & & $5=$ & 7 & 9 & \\
\hline
\end{tabular}

Figure 1. Claire's spreadsheet prepared for the post-awards meeting, where J1-6 are judges, and A-I are books. The highest ranked score is 9

In her desire for a more discursive approach to decision-making, and also to separate out the shortlisting and final decisions, Claire attempted to use the spreadsheet to show her fellow judges the variability of quantitative approaches. Indeed, in the subsequent years that Claire remained as a judge, the panel stopped using the voting system as the final decision-making mechanism, and the winner was decided at a later meeting. Claire articulated that "I felt slightly less frustrated as a consequence, but at the same time still didn't feel like we spent long enough discussing the titles under consideration, with a lot of store set by authors who were already highly acclaimed (ie a new [title by a highly acclaimed male author] would make it almost automatically onto the longlist)." Examples of Claire's frustration are evident in Stevie's fieldnotes and judging meeting transcripts. In one instance, the chair of the judges stated that the panel needed 'to proceed towards resolution', by means either of 'verbally knock[ing] out two of the three and be left with one survivor, or we can secretly ballot' (Marsden, 2014c). Claire responded that 'I honestly haven't made my mind up about these so I'd find it quite hard actually to vote, so I need to have more discussion.' A third judge commented, 'More discussion', followed by another saying that 'Yeah I think some discussion would be good' (Marsden, 2014c).

Nonetheless, in this meeting, the chair continued to discuss a voting system (the 'classic thing'), which led Claire to state that a judge could game the system by voting 'a little bit strategically' to get 'the title you want to win, to win'. A fourth judge then commented that, 'even now I'm not sure which I would put first', to which Claire responded 'that's what we've got to get to discursively, so everybody knows what they want...' The third judge then entered the conversation, saying 'don't we think as a group we could just discuss it a bit more and come to consensus?'. A fifth judge used a trope of reporting literary judging meetings (see Appleyard, 1991; Tonkin, 2005; Sanderson, 2017): 'I would much prefer [one of the three titles to win], but I wouldn't storm out in a rage for any of them'. This trope, accompanied by the fifth judge's ironic laughter, broke the tension, with the third, fourth and sixth judges agreeing. Following this, Claire again expressed her preference for everyone to discuss their favourite title, and during the ensuing conversation each judge openly stated who they wanted to win. The final decision was made without a secret ballot (Marsden, 2014c).

In our roles as researchers and participants, then, we both worked towards instigating and enacting change to the awards, sometimes in variance to existing practice of the long-serving judges, and sometimes even in conflict or disagreement with each other. In the next section, we focus on the question of gender, one which we both felt to have a problematic placing within the judging processes that we observed and of which we were part.

\section{GENDER AND JUDGING}

In the previous section, we discussed the point at which Claire made an intervention into the panel's predominantly quantitative judging processes, which led to the adoption of a more discursive approach. As a result Claire was, as mentioned previously, 'sligbtly less frustrated' with the judging process. Nonetheless, in her reflective 
notes, Claire referred to a male author she believed was frequently given a 'bye' onto the longlist. On further reflection, she thinks it possible that some female authors, as well as other men, benefitted from almost automatic longlisting. However, her frustration at the lack of a more discursive approach was exacerbated by the exclusion of the female author she thought should have been shortlisted. This section of the article focuses specifically on issues of gender and judging with regards to literary awards, and a particular moment at which both Claire and Stevie 'broke cover' and commented publicly upon their perspectives on being a judge and administrator. It does so with an awareness that other, intersectional, identities and demographics (e.g. race, class and sexuality) are also affected by literary prize culture, but due to our evidence base and the constraints of space, we focus on gender.

Both critical and journalistic literature on literary prizes discusses issues of gender (Demoor et al., 2008; Griffith, 2015; Marsden, 2019). Such analyses demonstrate that women are less likely to be longlisted and shortlisted for, or go on to win, major literary prizes than men. Practitioners have responded by setting up new prizes (in the UK, the Orange - subsequently Bailey's/Women's Prize for Fiction - in 1995; in Australia, the Stella Prize in 2013). In her blog, 'Books About Women Don't Win Big Awards: Some Data' (2015a), Griffith highlighted gender imbalances in literary awards. Her analysis provided statistical breakdowns of six major literary awards (the Pulitzer Prize, Man Booker Prize, National Book Award, National Book Critics' Circle Award, Hugo Award, and Newbery Medal) between 2000-2014, showing that the gender of characters, as well as authors, affects a book's success: '[w] hen women win literary awards for fiction it's usually for writing from a male perspective and/or about men' (Griffith, 2015a). In a later blog, Griffith added data from the IMPAC Dublin Award and the Costa Book Awards, with these statistics not only reiterating the gender imbalance Griffith had already highlighted, but also that 'the more consciously prestigious the award, the less likely the prize is to go [to] a woman writing about women' (Griffith, 2015b).

The same year, Hutcheson (2015) used Griffith's methodology to examine the literary environment in Scotland, analysing the winners of a number of Scottish literary prizes, noting that the Saltire Society's First Book of the Year had a 50\% split of male/female winners. However, this seemingly equal split obscured the fact that few of those winning books focused on a female protagonist, and one of the few that did, The Echo Chamber (2011), was written by a man, Luke Williams. The statistics for the Society's Book of the Year showed only 14\% of recipients were women. The only winner with a female protagonist, according to Hutcheson (James Kelman's Mo Said She Was Quirky (2012)), was written by a man. This data led Hutcheson to the damning conclusion that 'In 2012, the Society stated that "...this suite of awards truly reflects the commitment of civic Scotland to literature in all its forms." A grand claim - one that, alas, they haven't quite managed to reflect' (Hutcheson, 2015).

Griffith's and Hutcheson's blogs provided a moment at which Claire and Stevie's roles as prize judge and administrator came into conflict with their identities as feminists and researchers. Claire's reflective notes detail her actions in response to Griffith's and Hutcheson's blogs, commenting that (in the year after she had stopped being a judge), 'I wanted to add my voice to this, and in turn drafted a piece to publish on my own blog.' Claire sent a draft to the Society, explaining in her covering email that:

I've drawn (...) on my own experience of being a Saltire judge: could you take a look at it and let me know what you think? I want to be candid without being unduly or unnecessarily critical. Do you think this balance is OK? I've tried to make it as clear as I can that this is from my perspective, but I realise that I'm writing from a privileged position, and that if I were a Booker judge I'd have a gagging clause. (Squires, 2015b).

The Executive Director asked Claire for some changes to the draft, and to show it to the other judges. Claire commented in her notes that 'I understood the concern, and made changes as a consequence to the blog' prior to its publication (2015a). With agreement from the other judges, Stevie wrote a blog for the Society's website, which incorporated judges' responses to Claire's draft. These included one long-serving female judge suggesting that 'the balance between men and women writers in literary prizes is surely part of a long historical process' (Marsden, 2015). A more recently recruited male judge "was also sure there is no "conscious bias against women writers on our panel"" but agreed it was important to "look back over time at the trends" in order to establish where such biases originate' (Marsden, 2015). Another long-serving female judge commented that 'when she is "in the thick of a judging process" she is "very enthused about certain work regardless of gender and only tend[s] to think about gender balance retrospectively, sometimes too late"' (Marsden, 2015). As Stevie's blog observed:

From my experience, the gender of the authors of the books being discussed (...) is barely mentioned, and is by no means used as a deciding factor in the final valuation of the books (...). The current judges of the (...) Literary Award judging panel (...) have also expressed how, despite remaining keenly aware of gender imbalances in Scottish literature (and the arts in general), gender does not come into the conversations regarding the books they are adjudicating for the awards. (Marsden, 2015). 
Reflecting on her blog, Stevie wondered if she could have used it to interrogate the judges' comments more effectively. Stevie was aware of the existing discourse regarding gender imbalance in literary award culture when she started her $\mathrm{PhD}$, and dedicated a chapter of her thesis, 'The Saltire Society Literary Awards, 1936-2015: A Cultural History', to its analysis. ${ }^{3}$ While her research on gender informed the blog, it was written when Stevie was embedded in the Society, so it was possible that she unconsciously curtailed her response. More recently, Stevie revised and restructured her thesis chapter on gender for an article (Marsden, 2019). In the article, she conducts a quantitative analysis of male/female submissions, shortlistings and winners of the Society's First Book and Book of the Year from 1988-2014. Her findings provide further evidence that women are less likely to be shortlisted for, or win, literary prizes, indicating that the Society's awards replicate the gender imbalance present in other prizes. She argues that, while this imbalance may be influenced by inequality within the production and promotion of women writers in Scottish publishing more broadly, it may also be indicative of implicit stereotyping by the Society's judges. As interviews with current and former, male and female judges revealed, despite their repeated assertion that the judging panel had been gender balanced, this was not supported by Stevie's fieldnotes and research. Women did not make up 50\% of the Society's Literary Awards judges until 1999, seventeen years after the Book of the Year Award was established. When Stevie asked a former judge in interview if he had ever thought of inviting particular people to join the panel to ensure an even gender split, he responded: "Oh no, that way madness lies. You don't tailor your committee" (Marsden, 2014d). Such misalignment of the judges' perception of the prizes and the quantitative data suggests, Stevie argues, that there is a fundamental issue with the awards and their gender imbalance and this has reflected, and perpetuated, the historic trend of exclusion of women writers from the Scottish literary canon (Marsden, 2019). However, Stevie had not yet arrived at this critical reading of the awards when writing her blog in 2015. On reflection, she thinks she was influenced by her status as an embedded researcher:

I can definitely sense a change in my tone when reading this blog post in comparison to my article. The blog feels reserved and I do recall being aware that my response was perhaps considered by some as the Society's response. The lack of distance I had between my research and work. with the Society was, in fact, an issue that would come up on a number of occasions and for some of my thesis writing it was important that I was no longer working so closely with the Society to be able to apply a more critical reading to its work.

In our blogs, we both questioned whether the issues concerning gender imbalance and the Literary Awards could be considered in relation to the submissions and publication pipeline. Stevie noted that: "Since 1982 (...) more than 2,026 books have been submitted for the (...) Society's Book of the Year and First Book of the Year Awards [but] only 640 of these entries were authored, co-authored or edited by women" (Marsden, 2015). Reiterating this point, Claire wrote: "Judges work from submitted titles: are more books by men submitted for them to consider than by women? The answer for the Saltire Society is yes (...) Judges, therefore, are choosing from an already skewed list" (Squires, 2015a).

Given the unequal number of female/male-authored submissions, the question remains whether judges should be content to replicate the proportions submitted, or to bring the inequality into their discussions. For both of us, we would encourage the latter approach, believing that judging without discussing gender and other identities and demographics such as race, class and sexuality can reassert unconscious bias and power imbalances in the literary field (Nichols, 2015; Harvey and Lamond, 2016). Claire wrote in her blog that 'The publication of Griffith's data presents an opportunity for me to reflect on my own practice, as a scholar who studies literary prizes, a literary prize judge, and a feminist' (Squires, 2015a). In retrospect, Claire also noted that 'I did feel, as well, that although there might be an expectation of Chatham House rules with the prize, that sense of hiding away the decision-making process might, I felt, be inbibiting discussion of the awards in the media.' This approach led to Claire gaining funding for a subsequent collaborative doctoral award, 'Women of Words: Gender Equality in Contemporary Scottish Writing and Publishing' (Squires et al., 2017; SGSAH, n.d.), alongside the ROAR (Represent, Object, Advocate, Rewrite) working group for a potential prize for women's writing in Scotland (Reid, 2018).

A focus on questions of gender and the judging of the Saltire Society awards, then, reveals problematic areas in the intermingling of our roles, from Claire's concern about betraying the confidence of the judging room, to Stevie's reflection on how her positioning at the Society inflected how she wrote her blog. We both felt, and carefully considered, the tension of stepping out of the process, but also (as active researchers and feminists) of staying within it when we wanted to influence practice and critique the Literary Awards.

Indeed, these tensions have not disappeared, as the writing of this article itself has shown us. The Conclusion meditates upon the ongoing challenges of our positionings, but also demonstrates the value of embedded research, and what our collaborative autoethnographic frame brings to the study of literary prizes.

${ }^{3}$ Stevie is currently developing this thesis into a monograph for publication in 2020.

C 2019 by Author/s 


\section{CONCLUSION - THE RULES OF JUDGING CLUB}

'The First Rule of Judging Club' - pace Chuck Palahniuk's Fight Club (1996) - is not to talk about 'judging club'. This article, then, might represent a transgression of that 'rule', as we demonstrate some of the practices and behaviours (including our own) from inside the Saltire Society Literary Awards. As mentioned in Claire's email to the Society accompanying her draft blog, the Society does not require its judges to sign a 'gagging' clause like the Booker, but neither does it court controversy as larger prizes sometimes do (English 2005; Squires 2013; Driscoll, 2014; Flood, 2018c). Stevie's research at the Society was granted university ethics approval, the various interviews and meetings cited had consent from participants, and other documents quoted are either readily available in the public domain or accessible via the Society's archival holdings at the National Library of Scotland.

Nonetheless, both of us thought carefully about the ethics of writing this article. There was a tacit understanding among Society judges that they not discuss the decision-making process. Our multiple roles in relation to the Society, and indeed the Scottish publishing and writing community more widely, means we have collegiate relationships with participants in the field. Friendship, our close connections, and the intermingling of our roles, means that we both feel an 'enduring discomfort, in Stevie's words, at transgressing that 'First Rule', similar to sentiments expressed by other ethnographic researchers, such as Barton's feelings of guilt when conducting ethnographic research (Barton, 2011: 437).

In this article, we have revealed issues that frustrated us both, and how those frustrations (derived both from our ideological positionings and research backgrounds) sometimes worked to enact change. And yet we have held back some information, although not with the intent to tease or intrigue. We do not, as Claire noted, intend to be 'unduly or unnecessarily critical'. We sent a draft version of the article to current staff at the Society, wanting them to see it before it was published. We anonymised as much data as possible, even when we had ethics approval to use names. This article is not an exposé of 'Judging Club', even where we are recounting moments when we were frustrated with the practices of which we were part. Our continuing relationships delimit what we have recounted here, but also mean that we recognise again the privileged position - one of trust - that we had as 'researcher-inresidence' and 'researcher under cover' at the Society. Embedded researchers, including those on doctoral schemes such as the AHRC CDAs, face particular challenges and opportunities in their positioning, handling of data, and ability to retain critical distance while benefiting from being inside an organisation. As Neuwirth (2019) explores in her article in this special issue on her similarly embedded research for ROAR, underpinning a potential future prize for women's writing in Scotland, her role is as 'speculative archivist', contributing to the future history and 'greater narrative', as Stevie called it, of the prizes with which they are involved. The blurring of boundaries that such roles present are only partially mitigated and explained by documents and processes such as contracts between partners and research ethics documentation. As a consequence, we chose collaborative autoethnography for this article's methodology, as it allowed us to 'work together collaboratively to write, share, and analyze personal narratives as data' (Lapadat, 2017). In other words, collaborative autoethnography enabled the triangulation of our memories, fieldnotes and reflective commentary with archival records, interviews and judging meeting transcripts.

Part of our concern, as well as our collegiate relationships, derives from simultaneously wanting to understand, but not undermine, judging processes. This concern links to the contested question of 'whose cultural value', in Belfiore's words (2018). Moeran's exploration of jurying refers to the 'condition' that 'the organization should be able to identify objective differences that clearly demarcate potters and pots that are consecrated from those that are not' (2012: 14; citing Allen and Parson 2006: 810-11). It is this condition that makes the judging a 'black box for scholars' (2012: 3), and a necessity, Moeran argues, for prize organisers to retain:

Those who hand out awards and prizes must keep the processes of consecration secret in a black box if they are to maintain the legitimacy of those in whose trust they are placed. Otherwise it will become clear that the Emperor, while not entirely without clothes, may be somewhat improperly dressed for the occasion (2012: 15).

Are we, then, 'improperly dress[ing]' the Saltire Society in our autoethnographic account? We note that Moeran operated his own 30-year rule before publishing his material, while the particular instances we discuss above, and our involvement, are much more recent. Embedded research means that this is not a baring all of the judging process: we anonymised, held back from using some examples, or from critique. We have done this both because of our relationships, but also because we do not believe greater detail would actually have furthered a wider understanding of the judging processes. Ours is one of the very few scholarly explorations of cultural awards that has insight derived from the inside. Because of this positioning, this article has been able to reveal aspects of prize administration, organisational change, judging processes, and the ways in which the particular question of gender have troubled the Saltire Society Literary Awards. Moreover, we question whether, in fact, the 'processes of consecration' that Moeran refers to should be kept 'secret in a black box' in order to 'maintain (...) legitimacy'. Judging cultural awards is, based on our autoethnographical study, contextual, contingent, value-laden, and 
ideological, not objective. This observation aligns with that already proffered by scholars of literary prizes (e.g. English, 2005), but offers an amplified viewpoint derived from the inner workings of these particular awards. We argue that this interrogation of judging practices in literary award culture is necessary precisely because these processes are often deliberately opaque, in order to foster notions of prestige and exclusivity. Traditionally, readers might have been encouraged to accept judges' selections uncritically, but a number of literary awards (including the defunct Scottish Mortgage Trust Book Awards) have brought reader involvement to their heart, frequently by digital means (Squires, 2013: 301-2). The Saltire Society itself, at Stevie's instigation, introduced a series of shadow judging panels selected by the Society of Young Publishers, Scotland. As trusted participant observers of judging panel discussions, we offer something additional to these experiments, and different to the critique often found in journalistic accounts of prizes. Rather than expose vulnerabilities, this collaborative autoethnographic study aims to offer insight into literary gatekeeping, and present ways by which scholars might navigate their research alongside relationships with non-academic partners.

In breaking the seeming 'First Rule of Judging Club...', then, we also intend that this article offers productive reflections on embedded research by making evident its challenges and dilemmas of researching. The ethical framework for such research is far from simple, but in exploring particular moments with perspectives from both inside and outside the judging processes, and in interrogating the practices of literary gatekeeping and 21st century book culture research, we hope that this article casts light upon this particular judging club and its practices, but also illuminates ways in which researchers might consider, orientate, and carry out further research into processes of cultural consecration.

\title{
ACKNOWLEDGEMENTS
}

\author{
AHRC CDA Project Reference No. AH/J010200/1.
}

\section{REFERENCES}

Appleyard, B. (1991). Holes in the novel that all the Booker huffing and puffing can't fill. The Sunday Times, 29 September.

Arts and Humanities Research Council. (2015). Collaborative Doctoral Awards 2016: Scheme Guidance. Available at: https://ahrc.ukri.org/documents/guides/collaborative-doctoral-awards-2016-scheme-guidance/ (Accessed 18 April 2018).

Auguscik, A. (2017). Prizing Debate: The Fourth Decade of the Booker Prize and the Contemporary Novel in the UK. Bielefeld: transcript. https:// doi.org/10.14361/9783839438534

Barton, B. (2011). My Auto/Ethnographic Dilemma: Who Owns the Story? Qualitative Sociology, 34, 431-445. https://doi.org/10.1007/s11133-011-9197-x

Belfiore, E. (2018). Whose cultural value? Representation, power and creative industries. International Journal of Cultural Policy, 1-15. https://doi.org/10.1080/10286632.2018.1495713

Bochner, A. P. (1997). It's about time: Narrative and the divided self. Qualitative Inquiry 3(4), 418-438. https://doi.org/10.1177/107780049700300404

Bruner, J. (1993). The autobiographical process, in R. Folkenflik, (ed), The Culture of Autobiography: Constructions of Self-Representation (pp. 38-56). Stanford: Stanford University Press.

Cain, S. (2018). Helen Dunmore wins Costa book of the year for Inside the Wave. The Guardian, 30 January. Available at: https://www.theguardian.com/books/2018/jan/30/helen-dunmore-wins-costa-book-of-theyear-for-inside-the-wave (Accessed 18 April 2018)

Chang, H. (2008). Autoethnography as Method. New York: Routledge.

Coffey, A. (1999). The Ethnographic Self: Fieldwork and the Representation of Identity. London: Sage. https://doi.org/10.4135/9780857020048

Corse, S. M. (1996). Nationalism and Literature: The Politics of Culture in Canada and the United States. Cambridge: Cambridge University Press. https://doi.org/10.1017/CBO9780511557767

Datablog. (2012). Booker Prize 2012: Sales for all the winners and the 2012 shortlist, including Hilary Mantel. The Guardian, 10 October. Available at: https://www.theguardian.com/news/datablog/2012/oct/10/bookerprize-2012-winners-sales-data (Accessed 18 April 2018).

Demoor, M., Saeys, F. and Lievens, S. (2008) 'And the winner is?' Researching the relationship between gender and literary awards in Flanders, 1981-2000. Journal of Gender Studies, 17(1), 27-39. https://doi.org/10.1080/ 09589230701838370

Denzin, N. K. (1989). Interpretive Biography. Newbury Park, CA: Sage. https://doi.org/10.4135/9781412984584 
Denzin, N. K. and Lincoln, Y. S. (2000). Introduction: The discipline and practice of qualitative research, in N. K. Denzin, Y. S. Lincoln (eds.), Handbook of Qualitative Research (pp. 1-28). Thousand Oaks, CA: Sage.

Driscoll, B. (2014). The New Literary Middlebrow: Tastemakers and Reading in the Twenty-First Century. London: Palgrave Macmillan.

Ellis, C. and Bochner, A. P. (2000). Autoethnography, personal narrative, reflexivity, in N. K. Denzin, Y. S. Lincoln (eds.), Handbook of Qualitative Research (pp. 733-768). Thousand Oaks, CA: Sage.

Ellis, C., Adams, T. E. and Bochner, A. P. (2011). Autoethnography: An Overview. Forum Qualitative Sozialforschung / Forum: Qualitative Social Research, 12(1). https://doi.org/10.17169/fqs-12.1.1589

English, J. F. (2004). The Literary Prize Phenomenon in Context, in B. Shaffer (ed), A Companion to the British and Irish Novel, 1945-2000 (pp. 160-177). Oxford: Blackwell. https://doi.org/10.1002/9780470757611.ch11

English, J. F. (2005). The Economy of Prestige: Prizes, Awards, and the Circulation of Cultural V alue. Cambridge: Harvard University Press. https:// doi.org/10.4159/9780674036536

English, J. F. (2013). The Economics of Cultural Awards, in D. Throsby, V. Ginsberg (eds), Handbook of the Economics of Art and Culture (pp. 119-144). Amsterdam and New York: Elsevier. https://doi.org/10.1016/B978-0-444-53776-8.00006-4

Finlay, L. (2002). Negotiating the swamp: the opportunity and challenge of reflexivity in research practice. Qualitative Research, 2(2), 209-230. https://doi.org/10.1177/146879410200200205

Flood, A. (2011). Judge withdraws over Philip Roth's Booker win, The Guardian, 18 May. Available at: https://www.theguardian.com/books/2011/may/18/judge-quits-philip-roth-booker (Accessed 18 April 2018).

Flood, A. (2017). How to win a Booker prize: be under 50, enter your seventh book - about a man. The Guardian, 17 October. Available at: https://www.theguardian.com/books/booksblog/2017/oct/17/how-to-win-abooker-prize-be-under-50-enter-your-seventh-book-man-booker-prize (Accessed 18 April 2018).

Flood, A. (2018a). Women's prize for fiction reveals 'outward-looking' longlist. The Guardian, 9 March. Available at: https://www.theguardian.com/books/2018/apr/23/womens-prize-for-fiction-shortlist-newvoices-imogen-hermes-gowar (Accessed 18 April 2018).

Flood, A. (2018b). Man Booker International prize longlist: Han Kang up for top gong again. The Guardian, 12 March. Available at: https://www.theguardian.com/books/2018/mar/12/man-booker-international-prizelonglist-han-kang-laszlo-krasznahorkai (Accessed 18 April 2018).

Flood, A. (2018c). 'Over my dead body': Booker prize archives reveal unknown judging battles. The Guardian, 6 September. Available at: https://www.theguardian.com/books/2018/sep/06/over-my-dead-body-bookerprize-archives-reveal-unknown-judging-battles (Accessed 30 October 2018).

Freeman, M. (2004). Data are everywhere: Narrative criticism in the literature of experience, in C. Daiute, C. Lightfoot, (eds.), Narrative Analysis: Studying the Development of Individuals in Society (pp. 63-81). Thousand Oaks, CA: Sage. https://doi.org/10.4135/9781412985246.n14

Gale, K. and Wyatt, J. (2010). Between the two: A nomadic inquiry into collaborative writing and subjectivity. Newcastle: Cambridge Scholars Publishing.

Griffith, N. (2015a). Books about women won't win big awards: some data. Available at: https:/ / nicolagriffith.com/ 2015/05/26/books-about-women-tend-not-to-win-awards/ (Accessed 18 April 2018).

Griffith, N. (2015b). More data on gender and literary awards. Available at https://nicolagriffith.com/2015/08/06/ counting-and-gender/ (Accessed 6 March 2019).

Harvey, M. and Lamond, J. (2016). Taking the Measure of Gender Disparity in Australian Book Reviewing as a Field, 1985 and 2013. Australian Humanities Review 60, 84-107.

Hutcheson, L. (2015). Gender (In)Equality in Scottish Literary Prizes. Available at: https:/ /anovelbookblog.com/ 2015/06/02/gender-equality-in-scottish-literary-prizes/ (Accessed 28 August 2018).

Kawulich, B. B. (2005). Participant Observation as a Data Collection Method. Forum Qualitative Sozialforschung / Forum: Qualitative Social Research, 6(2). https:// doi.org/10.17169/fqs-6.2.466

Kelman, J. (2012). Mo Said She Was Quirky. London: Hamish Hamilton.

Lapadat, J. C. (2017). Ethics in Autoethnography and Collaborative Autoethnography. Qualitative Inquiry, 23(8), 589-603. https://doi.org/10.1177/1077800417704462

Marsden, S. (2012). Literary Panel Meeting Notes. 17 October. Edinburgh.

Marsden, S. (2013). Literary Award E-Book Administration. 9 January. Edinburgh.

Marsden, S. (2014a). Reinventing the Book': The Aesthetics of Digital Literature in Contemporary Literary Award Culture at By the Book: the Book and the Study of its Digital Transformation. Florence, 24 May.

Marsden, S. (2014b). The Saltire Society Book Awards Schema: Report, 3 February. Edinburgh.

Marsden, S. (2014c). Literary Panel Judging Meeting. Transcription, 24 September. Edinburgh.

Marsden, S. (2014d). Saltire Society Judge interviewed by Stevie Marsden, 8 April. Edinburgh. 
Marsden, S. (2015). Women in Saltire Literary Awards - A Discussion. Available at: http:/ /www.saltiresociety.org.uk/ news/2015/06/17/women-in-saltire-literary-awards-a-discussion (Accessed 28 August 2018).

Marsden, S. (2016). The Saltire Society Literary Awards, 1936-2015: A Cultural History (PhD thesis), University of Stirling, Stirling. Available at: http://hdl.handle.net/1893/24749 (Accessed 18 April 2018)

Marsden, S. (2019). Why Women Don't Win Literary Awards: The Saltire Society Literary Awards and Implicit Stereotyping. Women: a Cultural Review, 30(1), 43-65. https:/ / doi.org/10.1080/09574042.2018.1561047

McDermid, V. (2018). The inside story of judging the Man Booker prize 2018. The Guardian. Available at: https://www.theguardian.com/books/booksblog/2018/oct/17/inside-story-of-judging-man-booker-prize2018-val-mcdermid (Accessed 06 March 2019).

Méndez, M. G. (2014). Autoethnography as a research method: Advantages, limitations and criticisms. Colombian Applied Linguistics Journal, 15(2), 279-287. https:/ / doi.org/10.14483/udistrital.jour.calj.2013.2.a09

Menon, V. (2013). The Giller Effect. The Star, 1 November. Available at: https://www.thestar.com/ entertainment/books/2013/11/01/the_giller_effect.html (Accessed 19 April 2018).

Moeran, B. (2012). Awarding a Prize: An Ethnography of a Juried Ceramic Art Exhibition in Japan. Paper presented at 7 th Conference of the European Research Network Sociology of the Arts. 5-7 September. Vienna, Austria.

Neuwirth, C. (2019). Speculative Archiving of a Potential Future Literary Award: Embedded Publishing Studies Research. Journal of Cultural Analysis and Social Change, 4(2), 11. https://doi.org/10.20897/jcasc/6355

Nichols, C. (2015). Homme de Plume: What I Learned Sending My Novel Out Under a Male Name. Jezebel, 8 April. Available at: https://jezebel.com/homme-de-plume-what-i-learned-sending-my-novel-out-und1720637627 (Accessed 29 October 2018).

O’Brien, K. (2017). How to win the Man Booker Prize. The Bookseller, 16 October. Available at: https://www.thebookseller.com/booknews/how-win-man-booker-prize-655436 (Accessed 18 April 2018).

Pickford, S. (2011). The Booker Prize and the Prix Goncourt: A Case Study of Award-Winning Novels in Translation. Book History, 14, 221-240. https:/ / doi.org/10.1353/bh.2011.0004

Radway, J. (2000). A Feeling for Books: The Book-of-the-Month club, Literary Taste and Middle-Class Desire. London: University of North Carolina Press.

Rahim, S. (2012). Top five book judging controversies. The Telegraph, 25 January. Available at: https://www.telegraph.co.uk/culture/books/9038154/Top-five-book-judging-controversies.html (Accessed 18 April 2018).

Ramdarshan Bold, M. and Norrick-Rühl, C. (2017). The Independent Foreign Fiction Prize and Man Booker International Prize Merger: Can the Man Booker association help with the three per cent problem? Logos, 28(3), 7-24. https://doi.org/10.1163/1878-4712-11112131

Reid, K. (2018). Meet ROAR. Available at: https://womenslibrary.org.uk/2018/08/16/meet-roar/ (Accessed 27 August 2018)

Roberts, G. (2011). Prizing literature: the celebration and circulation of national culture. Toronto: University of Toronto Press. https://doi.org/10.3138/9781442694583

Saltire Society. (2014). Saltire Society Literary Awards 2014: Nomination Form. Edinburgh.

Saltire Society. (2015). The Saltire Society Literary Awards 2015: Ceremony Program. Edinburgh.

Saltire Society. (2016). Celebrating the Scottish imagination... Available at: http://www.saltiresociety.org.uk/aboutus / (Accessed 28 August 2018).

Sanderson, D. (2017). Book judge writes off prize chumps: David Sanderson gets the inside story on bungling, bullying and why politicians make the best chairmen. The Times, 1 April.

Scottish Graduate School for Arts \& Humanities. (n.d.) Women of Words: Gender Equality in Contemporary Scottish Writing and Publishing. Available at: http://www.sgsah.ac.uk/research/ces17-18/headline_569883_en.html (Accessed 28 August 2018).

Squires, C. (2007a). Book Marketing and the Booker Prize, in N. Moody, N. Matthews, (eds), Judging a Book by Its Cover: Fans, Publishers, Designers, and the Marketing of Fiction (pp. 71-81). London: Ashgate.

Squires, C. (2007b). Literary Prizes, in D. Finkelstein, A. McCleery, (eds), The Edinburgh History of the Book in Scotland Volume 4: Professionalism and Diversity 1880-2000 (pp. 264-266). Edinburgh: Edinburgh University Press.

Squires, C. (2007c). Literary Prizes, Literary Categories and Children's Literature in the 1990s-2000s, in V. Guignery, F. Gallix, (eds), Pre-and Post-Publication Itineraries of the Contemporary Novel in English (pp. 277-290). Paris: Editions Publibook Universite,

Squires, C. (2007d). Marketing Literature: The Making of Contemporary Writing in Britain (Basingstoke: Palgrave Macmillan).

Squires, C. (2011). Collaborative Doctoral Awards Proposal, 17 November.

Squires, C. (2013). Literary Prizes and Awards, in G. Harper, (ed.), A Companion to Creative Writing (pp. 291-304). Oxford: Wiley-Blackwell. https://doi.org/10.1002/9781118325759.ch19 
Squires, C. (2015a). Judging Women. Available at: https:/ / clairesquires.com/2015/06/05/judging-women/ (Accessed 28 August 2018).

Squires, C. (2015b). Judging Women. Email from Claire Squires, 2 June 2015 to Saltire Society staff.

Tonkin, B. (2005). Who'd be a Booker judge? The Independent, 21 January. Available at: https:/ /www.independent.co.uk/arts-entertainment/books/news/whod-be-a-booker-judge-16002.html (Accessed 18 April 2018).

Whitekirk, C. (2011). Report of the Saltire Commission. Edinburgh: The Saltire Society.

Williams, K. (2019). Facebook post, 4 March 2019. Available at: https://www.facebook.com/105791720544/ photos/a.10157971892285545/10161366824110545/?type=3\&theater (Accessed 06 March 2019).

Williams, L. (2011). The Echo Chamber. London: Hamish Hamilton.

Wischenbart, R., Genova, Y., Inkei, P., Kovac, M., Squires, C. and Torner, C. (2010). Feasibility Study on a Literary Translation Prize: Final Report. European Commission. Dr Rudiger Wischenbart Content and Consulting.

Wulff, H. (2017). Rhythms of Writing: An Anthropology of Irish Literature. London: Bloomsbury Academic. 